\title{
di Gléria János születésének 100 éves évfordulója
}

Intézetünk alapításának 50 éves jubileuma egybeesett di Gléria professzor, a magyar talajtani és agrokémiai tudomány jelentős alakja születésének centenáriumával.

di Gléria János 1899. április 11-én született Szombathelyen. A M. Kir. József Müegyetem Vegyészmérnöki Karának elvégzése után 'Sigmond Elek tanársegédjeként 1924-ben kezdte meg tudományos pályáját. Elsõ dolgozata 1926-ban „Tanulmány a talajok telítettségi fokának megismerésére" címmel a Kísérletügyi Közleményekben jelent meg. 1927-ben müszaki doktori képesítést szerzett. Ebben az évben került az Országos Chemiai Intézetbe, ahol később osztályvezetőként müködött.

1930-31-ben a Zürichi Müegyetemen - mint ösztöndíjas - Wigner professzor mellett fejlesztette tovább talajtani, fõleg talajkolloidikai, talajfizikai ismereteit. E téren elismert specialistává vált. 'Sigmond 1934-ben megjelent „Általános talajtan” kézikönyvében is ő írta a talaj vízgazdálkodásával, levegőtartalmával összefüggő fizikai jelenségekkel, továbbá az adszorpciós folyamatokkal foglalkozó fejezeteket. Mint 'Sigmond tanítvány és munkatárs a harmincas években részt vett a hazai szikkutatásban is. Több publikációban számolt be a szikes talajok keletkezéséről, a szikjavítási kísérletekröl.

A talajkémia és -fizika elméleti kérdései mellett a fiatal di Glériának különös tehetsége volt a talajvizsgálatokban használatos müszerek készítéséhez, s általában a módszertani kutatásokhoz. Többek között készüléket szerkesztett a talajok helyszíni vizsgálatára, számos cikkben számolt be a talaj-pH meghatározásának módszertani eredményeirõl, vizsgálta a talajrészecskék elektromos töltése és szerkezete közötti összefüggéseket. Kotzmann (Mados) Lászlóval együtt kidolgozták a talajtelítetlenség ammónium adszorpcióval történõ mérését. Munkatársaival, Schönfeld Sándorral, Telegdy-Kováts Lászlóval és Zukker Ferenccel több ízben számoltak be az Országos Chemiai Intézetben különbözõ módszerekkel végzett talajvizsgálatokról. A későbbiekben is jelentős szerepe volt a talaj adszorpciós komplexusának meghatározására alkalmas eljárások meghonosításában, továbbfejlesztésében.

Közismert, hogy a 'Sigmond-iskola tanítványait a mezőgazdasági kémia minden területe, sőt még a növénytermesztés egyes kérdéseinek széles körü ismerete is jellemezte. Így di Gléria János már pályája elején foglalkozott a növények táplálásával, a talajok tápelem-szolgáltatásával. Mattson, Parker és mások munkáit továbbfejlesztve kidolgozta a növények rendelkezésére álló makroelemek elektrodialízissel történõ meghatározását. Az Országos Chemiai Intézetben Telegdyvel együtt módosították a korszerü kolorimetrikus P-elemzési módszereket és behatóan vizsgálták a talajfoszfor oldhatóságát befolyásoló tényezőket. 
di Gléria jó matematikai felkészültsége megnyilvánult a tápelem-szolgáltatás elvi kérdéseinek tanulmányozásában is. Így pl. már 1933-ban megjelent a Mezőgazdasági Kutatásokban „A talaj tápanyagtartalma és a termés nagysága közti összefüggés matematikai kifejezése" címü dolgozata. Ebben bemutatta, hogy a különböző egyenletek mellett a parabolával is jól le lehet írni a tápelemtartalom és a termés összefüggését.

A 'Sigmond halála utáni időszak és a háborús évek kevéssé kedveztek a Chemiai Intézetben folyó talajtani, agrokémiai kutatásoknak. di Gléria Jánost 1942-ben a Budakeszi Mezőgazdasági Kísérleti Telep megszervezésével bízták meg. Kísérleti főigazgatóvá történt előléptetése után 1946-ban az Agráregyetem debreceni osztályán a Mezögazdasági Kémiai Tanszék vezetője lett. Emellett a Debreceni Tudományegyetemen, mint meghívott előadó a fizikai-kémia és kolloidika tanáraként is müködött. Az Agráregyetem átszervezésekor, a debreceni osztály megszünésével Budapestre került az Agrokémiai Intézetbe. Ott örömmel folytatta módszertani kutatásait, melyekből a talajok só-, valamint nedvességtartalmának meghatározásával kapcsolatos eredményeit publikálta. Jelentős munkát végzett a Ballenegger-Mados szerkesztette talajvizsgálati módszerkönyvben, majd a későbbi hasonló kiadványokban, „Az adszorpciós komplexus és a reakcióállapot vizsgálata" c. fejezetek megírásával. E helyeken ismertette többek között a talajban lejátszódó protolitikus folyamatok korszerủ elméletét is.

di Gléria professzort 1952-ben helyettes igazgatóvá nevezték ki, majd 1954-1959-ig mint igazgató vezette az Intézetet. Ezen időszak alatt részben a föhatóság (a Földmüvelésügyi Minisztérium), részben saját kezdeményezésére végrehajtott átszervezések során mindig arra törekedett, hogy a talajtani és agrokémiai kutatások színvonala fejlődjék. Nem kis része volt abban, hogy 1955-ben a Magyar Tudományos Akadémia lett az Intézet felügyeleti hatósága és 1957-től kezdve az MTA Talajtani és Agrokémiai Kutató Intézete néven vált a pedológiai, növénytáplálkozási és talajmikrobiológiai kutatások hazai központjává. Vezetési feladatai mellett folytatta kutatásait és főleg publikációs tevékenységét. Csaknem évenként jelentek meg nemzetközi elismertséget is jelentő kézikönyvei. Így 1957-ben került kiadásra Klimes-Szmik Andor és Dvoracsek Miklós társszerzőkkel írt „Talajfizika és kolloidika”, 1958-ban a „Mezőgazdasági kémia”, mely a növényi biokémiától a gyakorlati trágyázási ismeretekig a mai napig alapvető forrásmunkának tekinthető. Ugyancsak 1958-ban adta ki a Mezőgazdasági Kiadó di Gléria János szerkesztésében a „Mezőgazdák talajismereti és trágyázási útmutatóját".

di Gléria professzor nevéhez füződik a hazai mezőgazdasági kutatásban elsőként létesített izotóp laboratórium kialakítása is. Munkatársaival több publikációban, könyvrészletben számolt be az izotópok mezőgazdasági alkalmazásáról, illetve az ez irányú kutatási eredményeikröl.

1959-ben, hatvanadik életévét betöltve megvált igazgatói megbízásától, de tudományos tanácsadóként továbbra is folytatta kutatómunkáját és publikációs tevékenységét. Ballenegger és di Gléria szerkesztésében jelent meg 1962-ben a „Talaj- és trágyavizsgálati módszerek" címü több mint 400 oldalas módszerkönyv, mely csaknem 20 évig szolgált a társintézetekben, egyetemeken és egyéb intézményekben dolgozók részére hasznos útmutatással. Ugyancsak di Gléria professzor szerkesztésében jelent meg 1964-ben a „Mezőgazdák talajismereti és trágyázási útmutatójának” második, átdolgozott kiadása is. A klasszikus növényi tápelemek, elsősorban a foszforforgalommal 
foglalkozó munkái mellett a mikroelemek és serkentő anyagok hatékonyságát vizsgáló kísérletekröl is beszámolt munkatársaival.

1967-ben hosszabb kubai tartózkodásra vállalkozott több intézeti kollegával. A havannai Talajtani Intézetben megszervezte az izotópok mezőgazdasági felhasználásának kutatására alakult laboratóriumot és 1970-ig tartó munkássága során irányította az ez irányú kutatásokat, közremüködött a kubai szakemberek oktatásában, továbbképzésében.

Hazatérése után ugyan kisebb energiával, de továbbra is részt vett az Intézet, valamint az egész magyar mezőgazdasági tudomány életében. Számos állami és társadalmi kitüntetést kapott, több állami bizottságban, szerkesztőbizottságokban, a Magyar Talajtani Társaság elnökeként, ill. később tiszteletbeli elnökeként végzett tevékenysége során osztatlan megbecsülésben és elismerésben volt része. A fiatalabb munkatársainak, köztük nekem is, gyakran nyújtott értékes szakmai és emberi segítséget. Magánemberként is nyitott volt, intézeti rendezvényeken, közös nyaralásokon családját is módunkban volt megismerni. Közvetlen modorában gyakran beszélt ifjúkori élményeiről, a 'Sigmond laboratóriumban, az Országos Chemiai Intézetben történtekröl.

Mindazok, akik ismerték, mindig tisztelettel és szeretettel őrzik di Gléria János emlékét.

SARKADI JÁNOS

MTA Talajtani és Agrokémiai Kutatóintézet, Budapest 